\title{
Level of Sterility and Morphological Flowers Differentiation of Petaloid Male-sterile Plants of Carrot
}

\author{
Elżbieta U. Kozik (Corresponding author), Renata Nowak, Marzena Nowakowska \& Barbara Dyki \\ Department of Genetics, Breeding and Biotechnology of Vegetable Plants, Research Institute of Horticulture \\ ul. Konstytucji 3 Maja 1/3, 96-100 Skierniewice, Poland \\ Tel: 48-46-8334193 E-mail: ekozik@iwarz.pl
}

Received: April 29, 2011

Accepted: May 13, $2011 \quad$ Online Published: December 21, 2011

doi:10.5539/jas.v4n2p187

URL: http://dx.doi.org/10.5539/jas.v4n2p187

\begin{abstract}
Evaluation of the phenotypic uniformity within the carrot petaloid cytoplasmic male sterile (CMS) $\mathrm{BC}_{1}-\mathrm{BC}_{4}$ backcross populations in relation to several morphological traits of petaloidy expression was assessed. A high variability in the sterility level within and between most of the progenies was observed. As a result of the carried out investigations, the eight CMS lines could be divided into three groups according to the sterility level: $1 /$ one line with the highest number of male-sterile plants (100\%) occurring in all backcross populations of one line, 2/ four lines showed large shifts for the percentage of sterile plants as the backcross method progressed, $3 /$ three lines presented high fluctuations in the individual backcross populations. In 18 out of 25 male sterile backcross populations, white color of the corolla dominated (72\%) over green color and in most crosses the highest number of white-flowered petaloidy type was achieved for the populations most advanced in backcrossing. Examinations of the carrot flowers by means of the transmitted-light microscope revealed that majority of the populations were characterized by other beneficial morphological flowers traits: well developed nectarines, pistils, and styles.
\end{abstract}

Keywords: Cytoplasmic male sterility, Petaloid, Daucus carota, Breeding, Backcross

\section{Introduction}

Breeding of carrot (Daucus carota) hybrid cultivars, very pronounced in commercial production, is based on the development of inbred lines and incorporation of cytoplasmic male sterile (CMS) lines crossed with male fertile pollinators. Two morphologically distinct phenotypes of cytoplasmic male sterility are known: brown anthers (Welch and Grimball, 1947) and petaloids (Thompson, 1961). Brown-anther sterility is characterized by formed but unrolled, shriveled filaments and brownish anthers which are a result of tapetum degeneration (Michalik, 1971). Brown anther CMS was the first type used for developing hybrid carrot varieties, but recently petaloidy, the second type of sterility, is the more widely employed in carrot breeding programs, as CMS lines of the petaloid type have been found to maintain their male sterility better than those of brown-anther type (Davey, 1999; Bach et al., 2002). Petaloid sterility is manifested as the replacement of stamens with a second additional whorl of petals or petal-like, bract-like or carpelloid structures (Erickson et al., 1982; Kitagawa et al., 1994). Extensive genetic studies on carrot male sterility demonstrated a nuclear-cytoplasmic interaction for both CMS types. Thompson (1961) first described the cytoplasmic inheritance of petaloidy in carrot lines suggesting that the dominant alleles of each of the three duplicate nuclear genes, $M s 1, M s 2$, and $M s 3$, were necessary to maintain sterility for both cytoplasms, and dominant alleles at one or more epistatic loci could restore fertility (Timin and Vasilevsky, 1997). Contrary hypotheses were postulated for the brown-anther CMS system. The results of Hansche and Gabelman (1963), and Banga et al. (1964) suggested that expression of the brown-anther sterility was due to a homozygous recessive locus $M s 5$ or a dominant allele for $M s 4$, but dominant allele of either of the two complementary loci would restore the fertility.

Several authors report that both CMS systems can be influenced by specific environmental conditions, in particular high temperatures, which promote occurring fertile plants (Michalik, 1979; Mehring-Lemper, 1987; Wolyn and Chahal, 1998; Börner et al., 1995). The effects of restorers can also provide valuable information on the level of sterility, even if the genes involved are not formally identified (Budar and Pelletier, 2001).

In this study, evaluation of the phenotypic uniformity within the carrot backcross populations in relation to several morphological traits of petaloidy expression was assessed. 


\section{Materials and Methods}

\subsection{Plant material}

Eight male-sterile lines (A1, A2, A3, A4, A5, A6, A7, A8) and corresponding maintainer lines (B) bred at the Research Institute of Horticulture (RIH), Skierniewice, Poland, were used in this study. Male sterile lines (A) in their initial stage (before backcrossing) originated from the USDA carrot genetics and breeding program at Madison, Wisconsin, USA. Fertile lines (B) were bred at the RIH and originated from the material that has never been examined with regards to frequency of genes maintaining male sterility.

\subsection{Growth and culture}

The investigations were performed in 2001-2009. Every other year of the study, seeds were planted at the RIH, Skierniewice, Poland, in mid-May and roots were harvested during the final week of October. After vernalization at $2^{\circ} \mathrm{C}$, carrot roots were planted out during May in field. The soil type was a pseudopodsolic over loamy sand (1.15\% organic mater, $\mathrm{pH} 6.5)$. Fertilisation and plant protection against pests and diseases were provided according to current recommendations for carrot. For each of the studied populations of the eight male sterile lines (A), different number of plants in plots were planted at a distance of $25 \times 50 \mathrm{~cm}$. Five plants from each cross were planted in a greenhouse to perform consecutive backcross to the corresponding maintainer.

\subsection{Evaluation of the flower phenotype}

The carrot flowers were macroscopically observed every other day from the beginning of the first blooming umbel to the end of flower blooming in the rertiary umbels. A male-fertile flower of carrot has five petals and five stamens with cylindrical filaments, oval anthers on the top, and a pistil with two styles joined at the bottom (Fig. 1a). Male-sterile plants were characterized by lack of the stamens transformed into additional second whorl of petals with different shape, size, and color ranging from white to green (Fig. 1b-e, 2a-d). Flowers of all cytoplasmically male-sterile (petaloid) plants were classified also according to different transformation of petals into two subtypes: complete petaloidy, e.g. leafy petals (Fig. 1b), and other structures e.g. spoon-like, filamentous structure, lobed (Fig. 1c-e). Those genotypes which at the moment of flowering had several normally developed stamens on one or more umbels of the first and higher orders were classified as partially fertile.

To describe organ modifications and to permit accurate classification of the morphology, the carrot flowers were investigated under light microscope (x10) in some cases of the petaloids.

\section{Results and Discussion}

When the corresponding maintainers (B) of male-sterile cytoplasm were backcrossed to the eight petaloid (A) lines, a high variability in the sterility level within and between most of the progenies was observed and significant differences between them were noticed.

The highest number $(100 \%)$ of male-sterile plants occurred in the progenies of the $2 \mathrm{~A} \times 2 \mathrm{~B}$ cross and no male-fertile plants within all backcross populations $\left(\mathrm{BC}_{1}-\mathrm{BC}_{3}\right)$ were noted (Table 1). That may suggest a complementary action of sex determination genes in both $2 \mathrm{~A}$ and $2 \mathrm{~B}$ lines. The remaining seven crosses segregated in male fertile and male sterile plants in different backcross generations. The percentage of male sterility in their progenies was high, irrespective of the backcross generation. A significant progress in CMS lines development was also noticed in the second group of four crosses: $1 \mathrm{Ax} 1 \mathrm{~B}, 3 \mathrm{Ax} 3 \mathrm{~B}, 5 \mathrm{Ax} 5 \mathrm{~B}$, and $6 \mathrm{Ax} 6 \mathrm{~B}$. There were large shifts observed in the backcross ranks for the percentage of sterile plants as the backcross method progressed. The best results with $100 \%$ of sterile plants were recorded for the populations most advanced in backcrossing. It is noteworthy, that in their $\mathrm{BC}_{1}$ populations, the highest number of fertile plants was observed, but it gradually decreased in the consecutive backcrosses, and reached none in final populations. For the third and the last group of crosses $(4 \mathrm{Ax} 4 \mathrm{~B}, 7 \mathrm{Ax} 7 \mathrm{~B}, 8 \mathrm{Ax} 8 \mathrm{~B})$, a high fluctuations existed regarding the level of sterility in individual backcross populations in individual backcross populations. (Table 1). The lack of complementary genes responsible for male sterility in both A and B lines probably persisted.

It is characteristic, that partially-fertile plants were not detected in majority of the populations. Within only five backcross generations the contribution of partially fertile plants was as low as 2.2, 3.7 (3Ax3B), 3.0 (6Ax6B), 3.5 and $14.3 \%$ (7Ax7B) (Table 1). In contrast to these results, Morelok (1974) indicated a frequent occurrence of partially-fertile plants in the brown anther type of cytoplasmically-strerile carrot populations. Various studies showed partial reversion of fertility for both $\mathrm{cms}$ systems (brown-anther and petaloid sterility). Possible explanations for this phenomenon have been provided, for example, specific environmental conditions (Michalik, 1979; Mehring-Lemper, 1987), incomplete penetrance of maintainer genes and undiscovered restorer alleles (Wolyn and Chahal, 1998), or rearrangements in the mitochondrial genome (Chahal et al., 1998) and rearrangements of genes (Börner et al., 1995; Nakajima et al., 2001; Scheike et al., 1992; Szklarczyk et al., 
2000). Occurrence of the partially-fertile plants of carrot in this study appeared only at the beginning of backcrossing $\left(\mathrm{BC}_{1}\right.$ and $\left.\mathrm{BC}_{2}\right)$, except for cross $7 \mathrm{Ax} 7 \mathrm{~B}$, which was more labile and depending on the generation resulted in $3.5 \%\left(\mathrm{BC}_{1}\right), 0 \%\left(\mathrm{BC}_{2}, \mathrm{BC}_{3}\right)$ and $14.3 \%\left(\mathrm{BC}_{4}\right)$ of partially-fertile plants. Those results may suggest that carrot should be classified not only to the group for which the different growing temperatures play significant role in occurrence of the partially-fertile plants, but also to the other type which are genetically conditioned. That also revealed different properties of carrot and onion sterility depending on the source of sterile cytoplasm (Michalik, 1979).

Most of the petaloid CMS lines showed large variation range in corolla color and resulted in the distribution of the male-sterile plants over two color groups: white and green (Table 2). The group of white flowers, besides these of pure white, consisted of those that were halfway between green and white, and white with green stripes (Fig. 2a-d). In 17 out of the 25 studied male sterile backcross populations, white color of corolla dominated (68\%) over green color and in most crosses the highest number of white-flowered petaloid type was achieved for the populations most advanced in backcrossing as a result of selection towards white floral factor.

All male sterile flowers (petaloidy) of carrot lines were characterized by the lack of stamens that were replaced with petal-like organs, and spoon-shaped and/or filamentous structures, hereinafter called other structures (Fig. 1a-d). Petaloids with spoon-like structures were observed by others (Nothnagel et al., 1997; Wolyn and Chahal, 1998). No definite tendency could be found in the most advanced in backcrossing: $\mathrm{BC}_{3}$ and $\mathrm{BC}_{4}$ populations (Table 3). Taking into consideration the corolla color the intensity of the transformed petals into other structures predominated over petal-like organs in both in white- as well as in green-color flowers in most of the tested populations. In all male sterile flowers, irrespectively of the corolla color, the percentage of other structures and petaloid petals was very similar and reached $49 \%$ and $51 \%$, respectively (data not shown). Within the other structure group, the spoon-shaped structures dominated and the filamentous shape was the least common of petaloidy observed (Fig. 1c-e). Those differences in morphological structures of male sterile flowers within individual $\mathrm{BC}_{3}$ and $\mathrm{BC}_{4}$ populations might be due to the environmental influence on the expression of petaloidy, which has also been reported previously (Nieuwhof, 1974; Chadha and Frese, 1981). Other authors have also found complete petaloidy (Chadha and Frese, 1981), with normal structures but smaller in size (Eisa and Wallace, 1969) or less ovate (Linke et al., 1999).

The studied petaloid male-sterile plants also showed different morphological abnormalities including petals, pistils and nectaries (Fig. 3a,b). Most of these abnormalities were restricted to pistils, especially the number of styli; instead of two, none or three to six often developed. In some of the male-sterile flowers the ovaries were missing; more flowers with missing ovaries were noticed on higher-blooming umbels than on the main umbel. Ericson et al. (1982) has also observed morphological deformations ranging from slight twinning of styli (seen least frequently in white-corolla phenotypes) to multiple convoluted pistils (seen most frequently in the green-corolla phenotypes). In our study, the proportions of twinning of styli and twisting pistils were in almost the same ratio in green- as well as in white-corolla flowers (20-22\%; data not shown). Very similar results and relationships were obtained when the morphological observations of nectaries were carried out. Previous observations (Ericson and Peterson, 1979; Ericson et al., 1982), noted a higher number of green-corolla phenotypes of petaloid CMS lines (which developed smaller nectaries producing little or no nectar) than the white-corolla phenotypes. Contrary to these data, in our study the smaller and shrunken nectaries were seen in green-corolla florets $(20 \%)$ with almost the same intensity as those of white-corolla florets $(29 \%)$. In the genetically male-sterile lines and wild carrots, similar variability among petal and petaloid organs according to shape, size and composition of structure has been also noted (McCollum, 1966; Kitagawa et al., 1994). Such changes make the flowers less attractive for pollinating insects which may result in decreased number of seeds set (Erickson et al., 1982; Dyki et al., 2010). Green-flowered petaloid types, which were late ripening, were also found to be associated with the reduced seed production (Litvinova, 1988).

Clear differentiation among the newly obtained sources of petaloid male-sterile lines was possible based on the phenotypic relationships. High stability of the male sterility was observed in most of the crosses. Only three crosses differentiated in sterility and the number of fertile/sterile flowers fluctuating in their progenies. Possibly, changing the growing conditions influenced the level of sterility in consecutive backcross populations each year. Instability of the male sterility under specific conditions, mainly high temperatures, was demonstrated by Mehring-Lemper (1987) and Kaul (1988). Majority of the populations were characterized by advantageous morphological flowers traits: white corolla, well developed nectaries (Fig. 1f) and styles. Those constitute an interesting genetic source material as parent-seed component for subsequent breeding of carrot $\mathrm{F}_{1}$ hybrids.

\section{Acknowledgements}

The authors would like to gratefully acknowledge Prof. Barbara Michalik; (Agricultural University, Cracow, Poland) for critical reading of the manuscript and helpful insights. We are indebted to Dr. Marcin Nowicki, 
Research Institute of Horticulture, Skierniewice, Poland for skillful handling of the manuscript, translatory help and editorial assistance.

\section{References}

Bach, I.C., Olesen, A., \& Simon, P.W. (2002). PCR-based markers to differentiate the mitochondrial genomes of petaloid and male fertile carrot (Daucus carota L.). Euphytica, 127, 353-365. http://dx.doi.org/10.1023/A:1020314802236

Banga, O., Petiet, J., \& van Bennekom, J.L. (1964). Genetical analysis of male-sterility in carrots Daucus carota L. Euphitica, 13, 75-93. http://dx.doi.org/10.1007/BF00037521

Börner, T., Linke, B., Nothnagel, T., Scheike, R., Schulz, B., Steinborn, R., Brennicke, A., Stein, M., \& Wricke, G. (1995). Inheritance of nuclear and cytoplasmic factors affecting male sterility in Daucus carota. In: Kück, U., \& Wricke G. (Eds.). Genetic mechanisms for hybrid breeding. Blackwell Wissenschafts- Verlag, Berlin, $111-122$

Budar, F. \& Pelletier, G. (2001). Male sterility in plants: occurrence, determinism, significance and use. C.R. Acad. Sci., III 324(6), 543-550. http://dx.doi.org/10.1016/S0764-4469(01)01324-5

Chadha, M. L., \& Frese, L. (1981). Observations on a petaloidy type of male sterility in carrots (Daucus carota L.). Gartenbauwissenschaft, 46 (1): 21-24.

Chahal, A., Sidhu, H.S., \& Wolyn, D.J. (1998). A fertile revertant from petaloid cytoplasmic male-sterile carrot has a rearranged mitochondrial genome. Theor. Appl. Genet., 97(3), 450-455. http://dx.doi.org/10.1007/s001220050916

Davey, J.C. (1999). Deploying male-sterility as a grouping character in carrot distinctness, uniformity and stability trials. Proceedings of the Third International Symposium on the Taxonomy of Cultivated Plants. Edinburgh, UK, 20-26 July, 1998: 431-433.

Dyki, B., Nowak, R., \& Stepowska, A. (2010). The influence of flower structures on seeds productivity of the carrot breeding lines. Vegetable Crops Research Bulletin, 72, 5-13. http://dx.doi.org/10.2478/v10032-010-0001-3

Eisa, H. M., \& Wallace, D. H. (1969). Morphological and anatomical aspects of petaloidy in the carrot (Daucus carota L.). J.Amer. Soc. Hort. Sci., 94. 545-548.

Erickson, E.H., Garment, M.B., \& Peterson, C.E. (1982). Structure of cytoplasmic male-sterile and fertile carrot flowers. J. Amer. Soc. Hort. Sci., 107(4): 698-706.

Erickson, E.H., \& Peterson, C.E. (1979). Asynchrony of floral events and other differences in pollinator foraging stimuli between fertile and male-sterile carrot inbreds. J. Amer. Soc. Hort. Sci., 104 (5): 639-643.

Hansche, P.E., \& Gabelman, W.H. (1963). Digenic control of male sterility in carrots, Daucus carota L. Crop Sci., 3: 383-386.

Kaul, M.L.H. (1988). Male sterility in Higher plants. Pages 775-797 in: Monographs on Theoretical and Applied Genetics (Frankel, R., Grossman, M., and Maliga, P. eds.). Volume 10. Berlin, Heidelberg, New York: Springer.

Kitagawa, J., Gerrath, J.M., Posluszny, U., \& Wolyn, D.J. (1994). Developmental and morphological analyses of homeotic cytoplasmic male sterile and fertile carrot flowers. Sex Plant Reprod. 7, 41-50. http://dx.doi.org/10.1007/BF00241886

Linke, B., Nothnagel, T., \& Borner, T. (1999). Morphological characterization of modified flower morphology of three novel alloplasmic male sterile carrot sources. Plant Breed. 118, 543-548. http://dx.doi.org/10.1046/j.1439-0523.1999.00402.x

Litvinowa, M.K. (1988). Biology of flowering and pollination in fertile and male sterile forms of carrot, and seed production. Semenovodstvo Ovashchnykh Kultur: Sbornik Nauchnykh Trudov, Moscov, 58-66.

McCollum, G.D. (1966). Occurrence of petaloid stamens in wild carrot (Daucus carota) from Sweden. Economic Botany, 20, 361-367. http://dx.doi.org/10.1007/BF02904056

Mehring-Lemper, M. (1987). Genetisch-züchterische Untersuchungen zur Schaffung von Hybridsorten bei Möhren (Daucus carota L.). Dissertation, Universität Hannover.

Michalik, B. (1971). Genetic studies on male sterility in carrot Daucus carota L. Plant Breed. Acclimatization Seed Prod., 15: 445-474.

Michalik, B. (1979). Stability of male sterility in carrot under different growth conditions. De L'Academie Polonaise Des Sciences, 26(12): 827-832. 
Morelock, T.E. (1974). Influence of cytoplasmic source of expression of male sterility in carrot D. carota L. Ph.D. Thesis. Univ. of Wisconsin.

Nakajima, Y., Yamamoto, T., Muranaka, T., \& Oeda, K. (2001). A novel orfB-related gene of carrot mitochondrial genomes that is associated with homeotic cytoplasmic male sterility (CMS). Plant Molecular Biology, 46, 99-107. http://dx.doi.org/10.1023/A:1010652118518

Nieuwhof, M. (1974). The occurrence of self-incompatibility in cauliflower (Brassica oleracea var. botrytis L. subvar. cauliflora DC), and the possibilities to produce uniform varieties. Euphytica, 23, 474-478. http://dx.doi.org/10.1007/BF00022466

Nothnagel, T. Straka, P., \& Budahn, H. (1997). Development of new cms-system for carrot breeding. J. Appl. Genet., 38A: 172-177.

Scheike, R., Gerold, E., Brennicke, A., Mehring-Lemper, M., \& Wricke, G. (1992). Unique patterns of mitochondrial genes, transcripts and proteins in different male-sterile cytoplasms of Daucus carota. Theor. Appl. Genet., 83, 419-427. http://dx.doi.org/10.1007/BF00226529

Szklarczyk, M., Oczkowski, M., Augustyniak, H., Börner, T., Linke, B., \& Michalik, B. (2000). Organisation and expression of mitochondrial atp9 genes from CMS and fertile carrots. Theor. Appl. Genet., 100, 263-270. http://dx.doi.org/10.1007/s001220050035

Thompson, D.J. (1961). Studies on the inheritance of male-sterility in the carrot, Daucus carota L. var. sativa. Proc. Am. Soc. Hort. Sci., 78: 332-338.

Timin, N.I., \& Vasilevsky, V.A. (1997). Genetic peculiarities of carrot (Daucus carota L.). J.eurnal @f Appl.ted Genet.tes, 38A: 232-236.

Welch, J.E., \& Grimball, E.L. (1947). Male sterility in the carrots. Science 106, 594. http://dx.doi.org/10.1126/science.106.2763.594

Wolyn, D.J., \& Chahal, A. (1998). Nuclear and cytoplasmic interactions for petaloid male-sterile accessions of wild carrot (Daucus carota L.). J. Amer. Soc. Hort. Sci., 123(5): 849-835.

Table 1. Sterility level within various backcrosses of eight petaloid (A) lines and their corresponding maintainers (B)

\begin{tabular}{|c|c|c|c|c|}
\hline \multirow{2}{*}{ Cross } & \multirow{2}{*}{ Generation } & \multicolumn{3}{|c|}{ Number of plants $(\%)$} \\
\hline & & fertile & partially fertile & sterile \\
\hline \multirow{3}{*}{$1 \mathrm{Ax} 1 \mathrm{~B}$} & $\mathrm{Bc}_{1}$ & 25 & 0 & 75 \\
\hline & $\mathrm{Bc}_{2}$ & 0 & 0 & 100 \\
\hline & $\mathrm{Bc}_{3}$ & 0 & 0 & 100 \\
\hline \multirow{3}{*}{$2 \mathrm{Ax} 2 \mathrm{~B}$} & $\mathrm{Bc}_{1}$ & 0 & 0 & 100 \\
\hline & $\mathrm{Bc}_{2}$ & 0 & 0 & 100 \\
\hline & $\mathrm{Bc}_{3}$ & 0 & 0 & 100 \\
\hline \multirow{4}{*}{$3 \mathrm{~A} \times 3 \mathrm{~B}$} & $\mathrm{Bc}_{1}$ & 30.4 & 2.2 & 67.4 \\
\hline & $\mathrm{Bc}_{2}$ & 6.7 & 3.7 & 89.5 \\
\hline & $\mathrm{Bc}_{3}$ & 0 & 0 & 100 \\
\hline & $\mathrm{Bc}_{4}$ & 0 & 0 & 100 \\
\hline \multirow{2}{*}{$4 \mathrm{Ax} 4 \mathrm{~B}$} & $\mathrm{Bc}_{1}$ & 0 & 0 & 100 \\
\hline & $\mathrm{Bc}_{2}$ & 4.8 & 0 & 95.2 \\
\hline \multirow{4}{*}{$5 \mathrm{Ax} 5 \mathrm{~B}$} & $\mathrm{Bc}_{1}$ & 28 & 0 & 72 \\
\hline & $\mathrm{Bc}_{2}$ & 0.7 & 0 & 99.3 \\
\hline & $\mathrm{Bc}_{3}$ & 0 & 0 & 100 \\
\hline & $\mathrm{Bc}_{4}$ & 0 & 0 & 100 \\
\hline \multirow{3}{*}{$6 \mathrm{Ax} 6 \mathrm{~B}$} & $\mathrm{Bc}_{1}$ & 40.9 & 3.0 & 56.1 \\
\hline & $\mathrm{Bc}_{2}$ & 11.9 & 0 & 88.1 \\
\hline & $\mathrm{Bc}_{3}$ & 0 & 0 & 100 \\
\hline \multirow{4}{*}{ 7Ax7B } & $\mathrm{Bc}_{1}$ & 17.5 & 3.5 & 79 \\
\hline & $\mathrm{Bc}_{2}$ & 0 & 0 & 100 \\
\hline & $\mathrm{Bc}_{3}$ & 32.8 & 0 & 67.2 \\
\hline & $\mathrm{Bc}_{4}$ & 0 & 14.3 & 85.7 \\
\hline \multirow{2}{*}{$8 \mathrm{Ax} 8 \mathrm{~B}$} & $\mathrm{Bc}_{1}$ & 44.4 & 0 & 55.5 \\
\hline & $\mathrm{Bc}_{2}$ & 52.6 & 0 & 47.4 \\
\hline
\end{tabular}


Table 2. Corolla color differentiation in sterile plants of $\mathrm{cms}$ carrot lines

\begin{tabular}{|c|c|c|c|}
\hline \multirow{2}{*}{ Cross } & \multirow{2}{*}{ Generation } & \multicolumn{2}{|c|}{ Corolla color (\%) } \\
\hline & & white & green \\
\hline \multirow{3}{*}{$1 \mathrm{Ax} 1 \mathrm{~B}$} & $\mathrm{Bc}_{1}$ & 67 & 33 \\
\hline & $\mathrm{Bc}_{2}$ & 45 & 55 \\
\hline & $\mathrm{Bc}_{3}$ & 93 & 7 \\
\hline \multirow{3}{*}{$2 \mathrm{Ax} 2 \mathrm{~B}$} & $\mathrm{Bc}_{1}$ & 79 & 21 \\
\hline & $\mathrm{Bc}_{2}$ & 97 & 3 \\
\hline & $\mathrm{Bc}_{3}$ & 100 & 0 \\
\hline \multirow{4}{*}{$3 \mathrm{Ax} 3 \mathrm{~B}$} & $\mathrm{Bc}_{1}$ & 80 & 20 \\
\hline & $\mathrm{Bc}_{2}$ & 48 & 52 \\
\hline & $\mathrm{Bc}_{3}$ & 97 & 3 \\
\hline & $\mathrm{Bc}_{4}$ & 63 & 38 \\
\hline \multirow{2}{*}{$4 \mathrm{Ax} 4 \mathrm{~B}$} & $\mathrm{Bc}_{1}$ & 52 & 48 \\
\hline & $\mathrm{Bc}_{2}$ & 100 & 0 \\
\hline \multirow{4}{*}{$5 \mathrm{Ax} 5 \mathrm{~B}$} & $\mathrm{Bc}_{1}$ & 44 & 56 \\
\hline & $\mathrm{Bc}_{2}$ & 68 & 32 \\
\hline & $\mathrm{Bc}_{3}$ & 51 & 49 \\
\hline & $\mathrm{Bc}_{4}$ & 64 & 36 \\
\hline \multirow{3}{*}{$6 \mathrm{Ax} 6 \mathrm{~B}$} & $\mathrm{Bc}_{1}$ & 45 & 55 \\
\hline & $\mathrm{Bc}_{2}$ & 51 & 49 \\
\hline & $\mathrm{Bc}_{3}$ & 73 & 27 \\
\hline \multirow{4}{*}{ 7Ax7B } & $\mathrm{Bc}_{1}$ & 22 & 78 \\
\hline & $\mathrm{Bc}_{2}$ & 23 & 77 \\
\hline & $\mathrm{Bc}_{3}$ & 31 & 69 \\
\hline & $\mathrm{Bc}_{4}$ & 50 & 50 \\
\hline \multirow{2}{*}{$8 \mathrm{Ax} 8 \mathrm{~B}$} & $\mathrm{Bc}_{1}$ & 100 & 0 \\
\hline & $\mathrm{Bc}_{2}$ & 78 & 22 \\
\hline
\end{tabular}

Table 3. Occurrence of petal-like and other structures in male sterile flowers of the latest backcrosses of carrot

\begin{tabular}{|c|c|c|c|c|c|}
\hline \multirow{3}{*}{ Cross } & \multirow{3}{*}{ Generation } & \multicolumn{4}{|l|}{ Corolla color } \\
\hline & & \multicolumn{2}{|l|}{ white } & \multicolumn{2}{|l|}{ green } \\
\hline & & petal-like $\%$ & $\begin{array}{l}\text { other } \\
\text { structures \% }\end{array}$ & petal-like $\%$ & $\begin{array}{l}\text { other } \\
\text { structures \% }\end{array}$ \\
\hline $1 \mathrm{~A} \times 1 \mathrm{~B}$ & $\mathrm{Bc}_{3}$ & 100 & 0 & 50 & 50 \\
\hline $2 \mathrm{~A} \times 2 \mathrm{~B}$ & $\mathrm{Bc}_{3}$ & 0 & 100 & 0 & 0 \\
\hline $3 \mathrm{~A} \times 3 \mathrm{~B}$ & $\mathrm{Bc}_{4}$ & 40 & 60 & 0 & 100 \\
\hline $4 \mathrm{~A} \times 4 \mathrm{~B}$ & $\mathrm{Bc}_{2}$ & 68 & 32 & 0 & 0 \\
\hline $5 \mathrm{~A} \times 5 \mathrm{~B}$ & $\mathrm{Bc}_{4}$ & 45 & 55 & 81 & 19 \\
\hline $6 \mathrm{~A} \times 6 \mathrm{~B}$ & $\mathrm{Bc}_{3}$ & 21 & 79 & 14 & 86 \\
\hline $7 \mathrm{~A} \times 7 \mathrm{~B}$ & $\mathrm{Bc}_{4}$ & 100 & 0 & 0 & 100 \\
\hline $8 \mathrm{~A} \times 8 \mathrm{~B}$ & $\mathrm{Bc}_{2}$ & 0 & 100 & 50 & 50 \\
\hline & mean & 46.8 & 53.3 & 24.3 & 50,6 \\
\hline
\end{tabular}



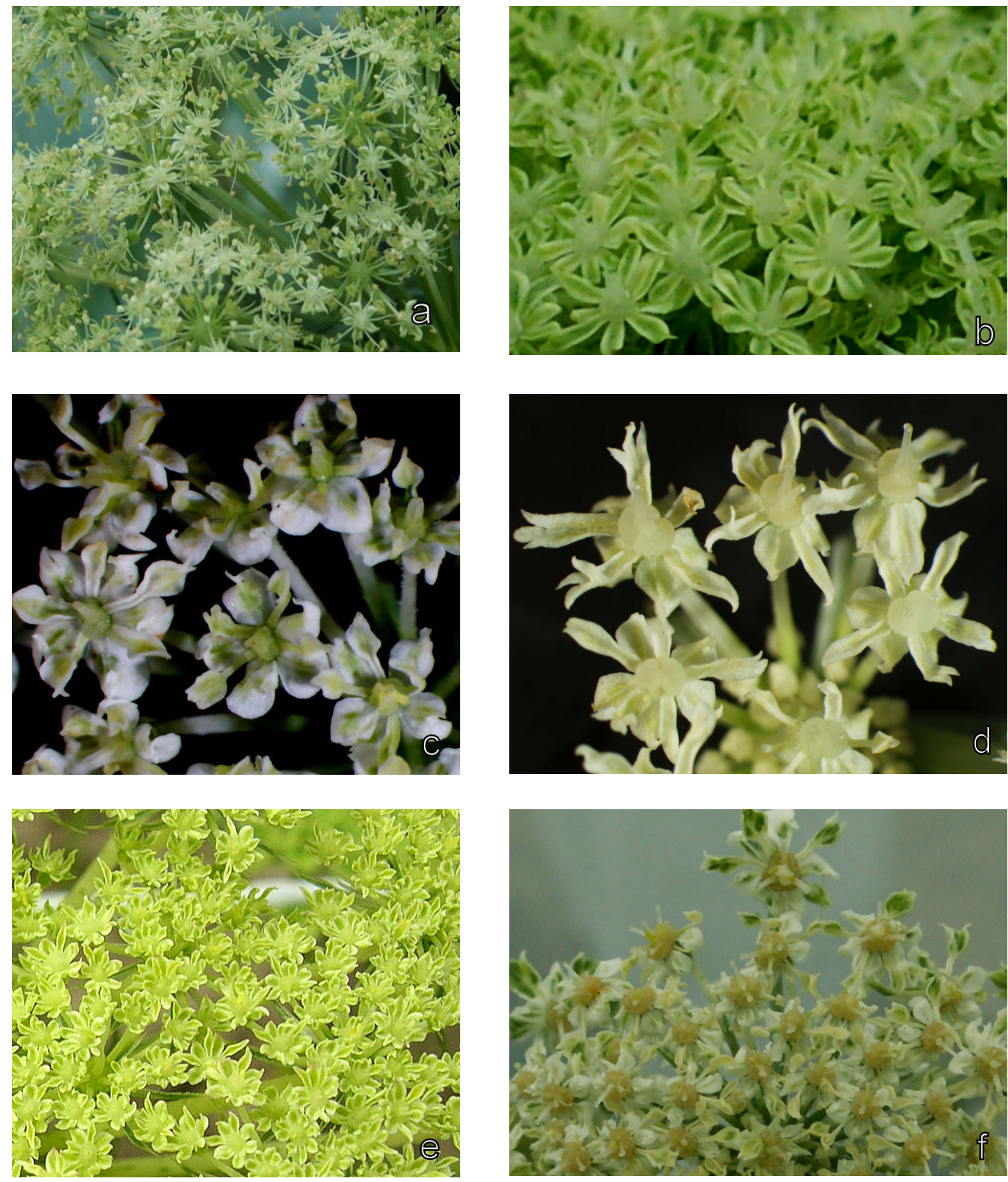

Figure 1. Umbelets and flowers of fertile (a) and cytoplasmically male-sterile plants of carrots with differentially transformed of $\mathrm{cms}$ petals into complete petaloidy (leafy petals) (b), and other structures: spoon-like (c), lobed (d), filamentous (e), and well developed nectaries (f) 

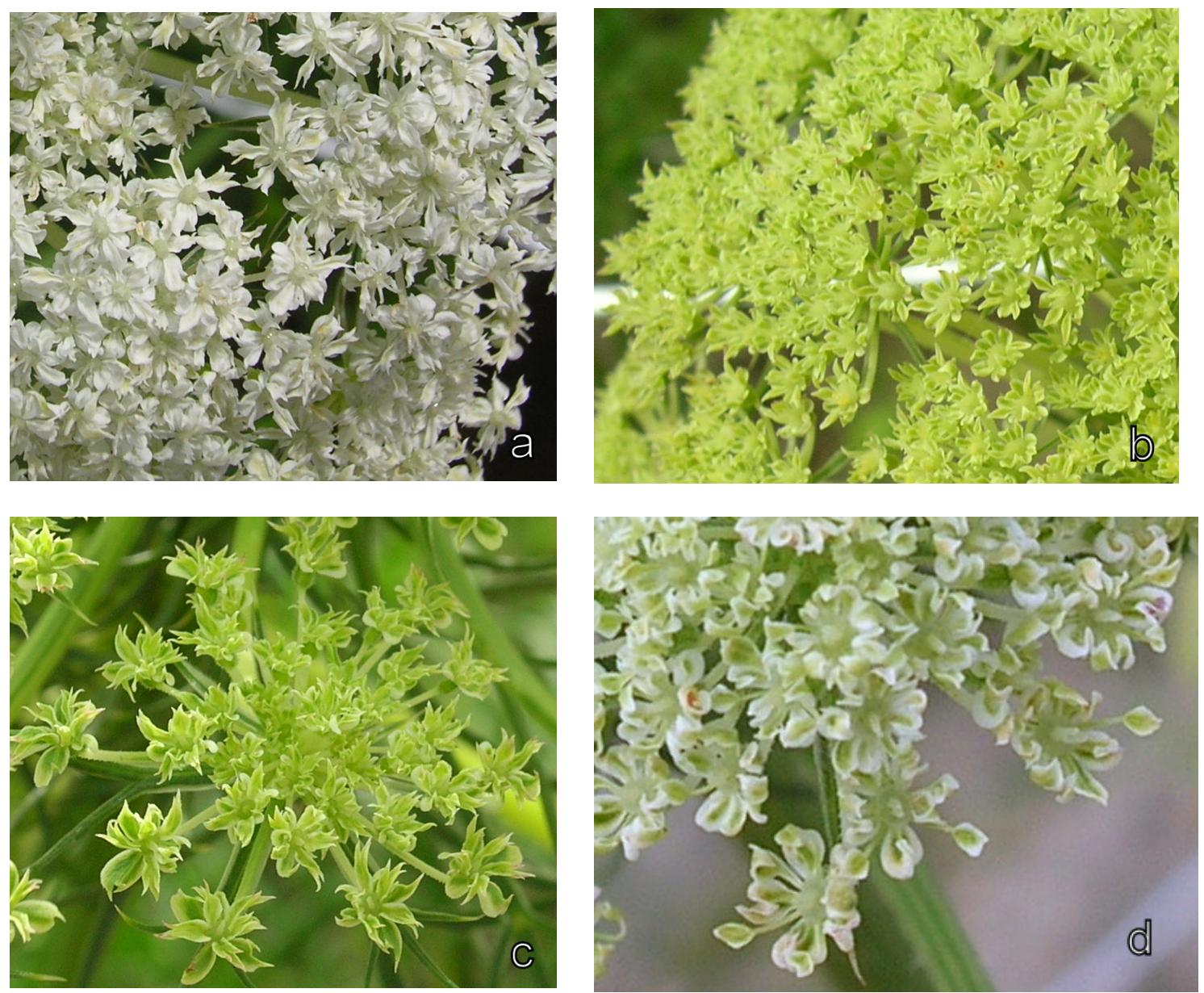

Figure 2. Colours of petalods petals: white (a), green (b), halfway green (c), white with green stripe (d)
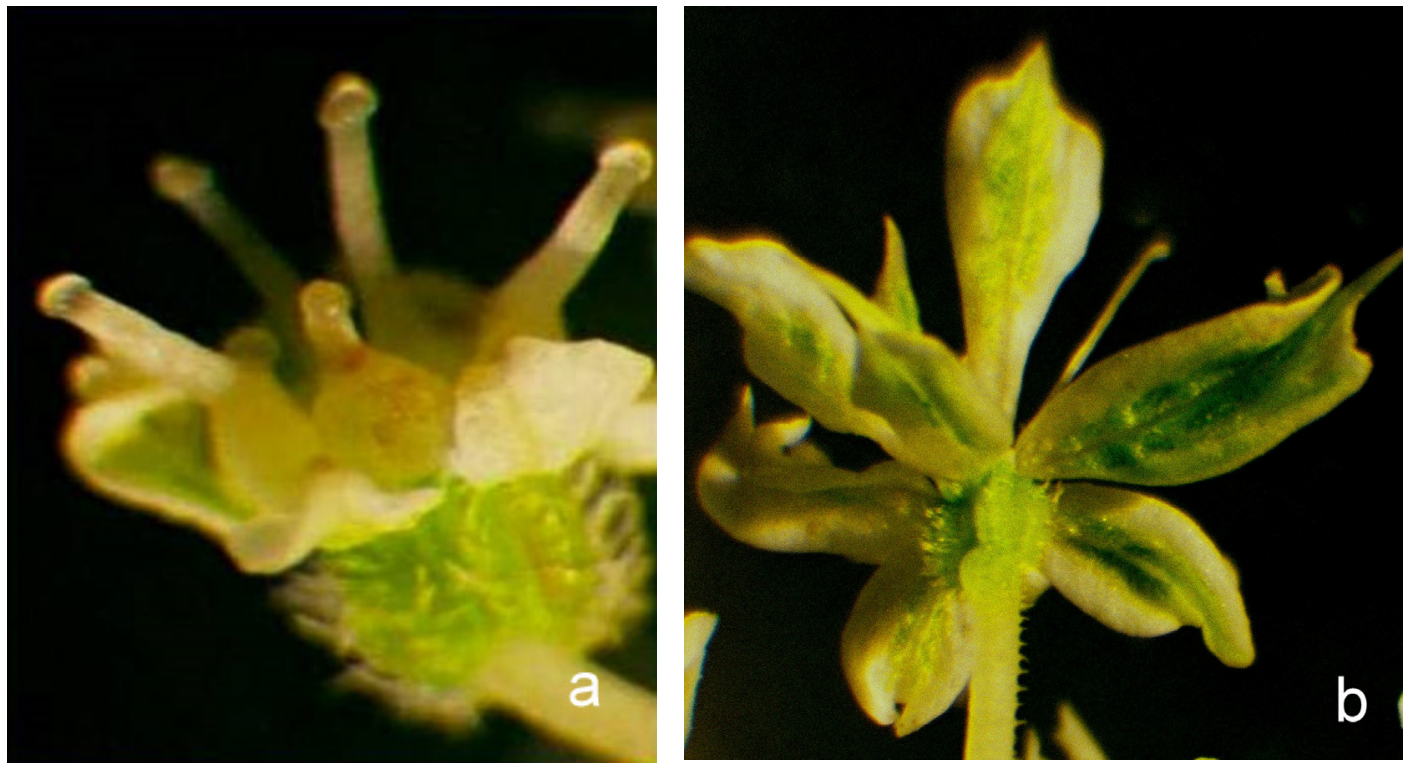

Figure 3. Morphological abnormalities of $\mathrm{cms}$ flowers: multiple styles (a), missing ovary (b) 